\title{
Martin Scorsese Biopics: visual memory for the future
}

\author{
Denize Araujo \& Cynthia Schneider*
}

Resumo: O objetivo deste texto é analisar três biopics de Martin Scorsese, questionando se podem funcionar como fonte de memória visual/testemunho para o futuro, mesmo que a subjetividade interfira na montagem de documentários sobre Cinema e Teatro, Literatura e Música. Em relação ao tom e construção dos biopics, os nomeamos como "selfie-biopic", "accomplice-biopic" e "tribute-biopic". O corpus principal deste estudo inclui documentários em três mídias: um "cúmplice-biopic" sobre o diretor de cinema e teatro Elia Kazan, Uma carta para Elia (2010); um "selfiebiopic", Public speaking (2010), sobre o escritor Fran Lebowitz; e uma "biografia de tributo" sobre a música, George Harrison vivendo no mundo material (2011), retratando o guitarrista dos Beatles. O referencial teórico inclui os conceitos de memória subjetiva de Beatriz Sarlo e o estudo de intertextos de Julia Kristeva. Os conceitos de Bill Nichols e Fernão Ramos são relevantes para a definição de documentários modernos, bem como a história do documentário de Deane Williams.

Palavras-chave: documentário; subjetividade; memória visual; "selfie-biopic"; "cúmplice-biopic"; "tributo-biopic".

Resumen: El objetivo de este texto es analizar tres películas biográficas o biopics de Martin Scorsese para saber si pueden funcionar como una fuente de memoria visual o un testimonio para el futuro, aun cuando la subjetividad interfiere en los montajes de documentales sobre cine y teatro, literatura y música. Teniendo en cuenta el tono y la construcción de los biopics, los denominamos selfie-biopic, biopic-cómplice y biopictributo. El corpus principal de este estudio incluye documentales en tres formatos: un "biopic-cómplice" sobre el director de cine y teatro Elia Kazan, A letter to Elia (2010); un "selfie-biopic" sobre el escritor Fran Lebowitz, Public speaking (2010); y un "biopic-tributo" sobre música, George Harrison, living in the material world (2011), que retrata al guitarrista de los Beatles. El marco teórico de referencia incluye el concepto de memoria subjetiva de Beatriz Sarlo y el estudio de los intertextos de Julia Kristeva. Los conceptos de Bill Nichols y Fernão Ramos, así como la historia del documental de Deane Williams, son relevantes para la definición de los documentales actuales.

Palabras clave: documental; subjetividad; memoria visual; "selfie-biopic"; "biopiccómplice"; "biopic-tributo".

* Denize Araujo: Universidade Tuiuti do Paraná - UTP, Programa de Pós-Graduação em Comunicação e Linguagens. 82010330, Curitiba, Paraná, Brasil.

E-mail: denizearaujo@hotmail.com

Cynthia Schneider: Universidade Tuiuti do Paraná - UTP, Programa de PósGraduação em Comunicação e Linguagens. 82010330, Curitiba, Paraná, Brasil. E-mail: cyls72@uol.com.br

Submission of the article: september $17^{\text {th }} 2018$. Notification of acceptance: october $21^{\text {st }} 2018$. 


\begin{abstract}
The aim of this text is to analyze three biopics by Martin Scorsese, questioning whether they can function as a source of visual memory/testimonial for the future even if subjectivity interferes in the documentaries montages about Cinema and Theatre, Literature and Music. Regarding the tone and construction of the biopics, we nominated them as "selfie-biopic", "accomplice-biopic" and "tribute-biopic". The main corpus of this study includes documentaries in three media: an "accomplicebiopic" about the film and theatre director Elia Kazan, A letter to Elia (2010); a "selfie-biopic", Public speaking (2010), about the writer Fran Lebowitz; and a "tribute biopic" about Music, George Harrison, living in the material world (2011), portraying the Beatles guitarist. The theoretical frame of reference includes Beatriz Sarlo's concepts of subjective memory and Julia Kristeva's study of intertexts. Bill Nichols and Fernão Ramos' concepts are relevant for the definition of modern documentaries as well as Deane Williams' history of documentary.

Keywords: documentary; subjectivity; visual memory; "selfie-biopic"; "accomplicebiopic"; "tribute-biopic".

Résumé : Le but de ce texte est d'analyser trois biopics de Martin Scorsese, en se demandant s'ils peuvent fonctionner comme une source de mémoire visuelle ou un témoignage pour le futur, même si la subjectivité interfère dans les montages documentaires sur le cinéma et le théâtre, la littérature et la musique. En ce qui concerne le ton et la construction des biopics, nous les avons nommés «selfie-biopic», «complice-biopic» et «tribute-biopic». Le corpus principal de cette étude comprend des documentaires de trois types : une biographie complice sur le metteur en scène de théâtre et réalisateur Elia Kazan, Uma carta para Elia (2010) ; un «selfie-biopic», Public Speaking (2010), sur l'écrivain Fran Lebowitz; et un «biopic hommage» sur la musique, George Harrison vivendo no mundo material (2011), évoquant le guitariste des Beatles. Le cadre de référence théorique comprend les concepts de la mémoire subjective de Beatriz Sarlo et l'étude des inter-expressions de Julia Kristeva. Les concepts de Bill Nichols et de Fernão Ramos sont pertinents pour la définition du documentaire moderne ainsi que pour l'histoire du documentaire de Deane Williams. Mots-clés : documentaire ; subjectivité ; mémoire visuelle ; «Selfie-biopic» ; «Complice-biopic»; «Hommage biopic».
\end{abstract}

\title{
Introduction
}

This study is part of our coauthored research, Denize Araujo as Supervisor and Cynthia Schneider as Post-Doctorate recipient of a PNPD scholarship from UTP- Universidade Tuiuti do Paraná, Brazil. The aim of this research is to analyze three biopics by Martin Scorsese, questioning whether they can be testimonials or visual memories for the future.

The production of biopics or cinebiographies - documentaries about recognized icons in various areas of knowledge - has been emphasized in the last decade, although some biopics have been criticized for inserting information not allowed by family members, as in the case of the singer Amy Winehouse and Grace Kelly, Princess of Monaco. 
Interactions between cinema and art can follow three concepts: art-cinema, which is a film with aesthetical and artistic elements; cinema about art, in the case of representations of art movements; and cinema about artists, as in this case. Having as corpus three biopics by Scorsese, one about Elia Kazan, theater and film director, A Letter to Elia (2010), another about literature, having Fran Lebowitz as protagonist, Public Speaking (2010), and one about one of the Beatles, George Harrison: living in the material world (2011), we classified them as "accomplice-biopic", "selfie-biopic' and "tribute-biopic", respectively.

The main objective of this study is to find out whether these biopics can be a source of knowledge or visual memory for the future. The specific objective is to verify to which extent subjectivity can interfere in the form and essence of the films and affect the power of memory. The focus and points of view in the three films take us to question the role of emotion and indifference, affection and performance, allowing a differential among the productions and a specific denomination for each documentary. For Fran Lebowitz, Scorsese gives complete liberty of action, making the protagonist the show itself, what we consider a "selfie-biopic". On the other hand, the filmmaker positions himself together with Elia Kazan in a subjective and intimate way, endorsing Kazan's actions, which could be taken as an "accomplice-biopic". George Harrison, the leader guitarist of the Beatles, is remembered in a long visual documentary (more than 3 hours) which contemplates the oriental spirituality of the musician, his photos since childhood and his battle against cancer. We classified it as a "tribute-biopic".

Our main theoretical reference frame includes Beatriz Sarlo's concepts about subjective memory and Julia Kristeva's concept of visual intertextuality for interactions among film clips, interviews and photos. Regarding documentary as a cinematic genre, the basic concepts are by Bill Nichols and Fernão Ramos, having Michael Renov and Noel Carroll's concepts about the role of subjectivity in documentary montages.

One of the pillars that may support the assertion that documentaries can be sources of visual memories in the future is their classical search for faithful representation. However, the subjectivity that permeates most of them allows diverse points of view and montages that justify our studies that intend to analyze individually the three biopics in order to differentiate them. The assertion that all is fiction or all is documentary, functioning as thesis-antithesis, can lead to a synthesis as a possibility of a hybrid montage that may document factuality in a creative way. 


\section{Documentary, memory and subjectivity}

It has been said that the Scottish documentary filmmaker John Grierson coined the term "documentary" in his review of the film Moana, by Robert Flaherty (1926). We would say that Flaherty's Nanook of the North (1922) could also be labeled as "documentary" and even a biopic, considering that the protagonist is more emphasized than anything else. It is exactly Grierson's definition of "documentary- a creative treatment of reality" that allowed him to use the term in a more ample scale, if we think that Nanook, for the sake of the film, had to use some techniques that were not in use anymore, questioning the faithfulness of the classical characteristic of documentary. Even nowadays, when the term is discussed by many scholars, Grierson's definition might be considered the best one, the one that can be used now, when documentaries are hybrid, distinguished by terms such as fake, mockumentary, docudrama, dramadoc and so on.

Creativity and subjectivity can be characteristics that belong to biographical documentaries as well. Interviews can be testimonials if we accept the use of the term "metamorphosis-memory", which means that our memory can change according to our points of view, our cultural background and our acquired knowledge through life. Our perceptions can change and many times what we believed to be an assertion in the past can become a doubt when our repertoire turns to be a source of emotional views. Besides, our memory deterritorializes and reterritorializes according to changes of time and place and to reflections that tend to mould our lives taking us to rethink and add or even change concepts that are no longer adequate to our social and cultural lives. Beatriz Sarlo, in her book Time past: the culture of memory and the subjective turn (2007), states that

The prefix "post" indicates what comes after memory from the ones that lived the facts and that, establishing with memory this relation of posterity, also have conflicts and contradictions that are characteristics of the intellectual analysis of a discourse about the past and its effects about sensitivity (Sarlo, 2007: 92).

This idea of a "post-memory" can be applied to biopics that determine what kind of inclusions they can have to be perpetuated towards the future. This is the reason why biopics are complex films to deal with. They can be responsible for wrong analysis based on one person's character portrayed in a subjective way. Sarlo also states that

The past is always conflicted. To the past, memory and history concur. Not always history can believe in memory and memory does not trust a reconstitution that does not have in its centre the rights of remembering (rights of life, 
of justice, of subjectivity). To think that it could exist an easy understanding between these perspectives about the past is a desire or a commonplace (Sarlo, 2007: 9).

Many scholars have given their interpretations about documentaries, testimony, subjectivity and memory, including the most memorable ones and some points of view that have been frequently cited. Paula Rabinowitz, in her book They must be represented (1994), believes that

Testimony is always a partial truth, so when filmmakers authorize their subjects to speak and thus provoke their audiences to act, it can only be a supplementary gesture toward truth. Yet, the "political" documentary often fails to register this, presenting, like the ethnographers, the appearance of "wholeness" (Rabinowitz, 1994: 28).

In order to avoid using the word "truth" or "reality", we, the coauthors of this text, decided to use the term "factuality". Even this term, however, implies subjective connotations, as well as the unclear division between fiction and documentary.

Manuela Penafria suggests that "in the same way that fiction integrates documental elements, also documentaries have fictional elements" (Penafria, 1999: 21). John Green, in An abundance of Katherines, said: "You don't remember what happened. What you remember becomes what happened". Harold Pinter in Old Times said that "there are some things one remembers even though they may never have happened".

Bill Nichols, in his chapter "How do documentaries differ from other types of film?" from the book Introduction to Documentary (2001), questions: "What assumptions and expectations characterize our sense that a film is a documentary? What is a documentary? What do we bring to the viewing experience that is different when we encounter what we think of as a documentary rather than some other genre of film? "Nichols' assertion is that people assume that sounds and images have their origin in the historical world. He believes that this assumption comes from realism, from an authenticity of evidence. However, he explains, "we must always assess the argument or perspective on grounds that include but go beyond factual accuracy". Nichols complements that

this assumption carries more weight in a film we take to be a documentary than in a film we take to be a fiction. It is for this reason that we may feel cheated when we learn that a work we thought was nonfiction proves to be a fiction after all. The line dividing the two may be imprecise or fuzzy, but we tend to believe in its reality all the same (Nichols, 2001: 20-40).

We agree partially with Nichols. Spectators and scholars do not expect documentaries to be a copy of "reality" neither they ignore the sound and im- 
age effects in our digital media era. Our expectations are satisfied if we can see creativity in a film as the Blair Witch, that resembles a documentary in its narrative and tone, but is a fake one. Another example is Watermelon Woman, by Cheryl Dunye, that has all elements of a documentary, including interviews about a black singer who had been forgotten and needed recognition. The film also displays cameo characters such Camille Paglia that was naïve enough to say that she knew that black singer. The last words of the film announce that it was all a creation: a fake biopic dedicated to black actresses. The director, in this case, was sued by the unreliability to present a project for a documentary, asking for a grant and then to develop a different film.

Fernão Ramos believes that documentaries that use persuasion should be called "cable documentaries":

A cable documentary is an assertive documentary. However, contrary to the classical one, the assertions are established by multiple voices... in interviews, testimonials, archive material, dialogs. The multiplicity of voices does not exclude, however, the assertion of knowledge expressed by the cable documentary, within an ideological context similar to the classical documentary (Ramos, 2008: 41).

Noel Carroll, in his chapter "From Real to Reel: entangled in nonfiction film", in his book Theorizing the moving image, makes commentaries about Metz's famous "all films are fictional". Instead, Carroll suggests that all films are mediated. He clarifies: "Nonfictional films are those that we evaluate on the basis of their knowledge claims in according to the objective standards appropriate to their subject matter" (Carroll, 1996: 237). These notions may be the origin of Carroll's Keynote Speech at the Opening of the XX SOCINE-UTP 2016, when he talked about his concept of evaluative heuristic: "my notion of The Evaluative Heuristic better serves our "post medium" moving-imageworld, insofar as it regards each convergence of media as a discrete artwork - as a singularity." This concept may solve controversial statements about the status of documentaries nowadays.

\section{Origin and development of biopics}

According to Tom Brown and Belén Vidal, at the Oxford Bibliographies, biopic is the most common term used to refer to films representing any aspect of the lives of famous people from the past or the present. The term seems to have originated in the trade papers and then penetrated the consciousness of producers and critics. Its widespread use has replaced the more formal "biographical picture." 
Originally associated with the prestige pictures produced by Hollywood studios during the classic era, the term has also become naturalized in the domain of British cinema (particularly with the consolidation of studies on heritage cinema). "Biopic" has also entered (not without certain resistance) the vocabulary of the study of other national cinemas, such as the French cinema. While George Custen's 1992 study of the studio biopic established the foundations for its study as a Hollywood genre, the debates about the biopic have pursued several lines of inquiry from the start. On the one hand, the genre was perceived as a belated offspring of popular biographical formats at a time (the early 20th century) when literary biography was moving to new and experimental forms of life writing. On the other, the biopic began to be studied as a form of historical cinema, and as such it could become the target of historians' concerns about fidelity and mis-representation, agency, and the ideological subtexts underpinning the retelling of history as well as the reconstruction of national narratives. (www.oxfordbibliographies.com/view/document)

If this is one side of the origin, there is another side stated at the filmsite.org, written and edited by Tim Dirks. According to Dirks, "biopic films (or biographical pictures) are a sub-genre of the larger drama and epic film genres, and although they reached a hey-day of popularity in the 1930s, they are still prominent to this day". Dirks mentions that

biopics have existed since the earliest days of silent cinema in films such as French filmmaker Georges Melies' feature-length epic Jeanne D'Arc (1899) and Cecil B. DeMille's Joan the Woman (1916), D.W. Griffith's religious epic Judith of Bethulia (1914), Abel Gance's innovative six-hour-long epic Napoleon (1927), and director Lloyd Ingraham's Jesse James (1927) with Fred Thomson as the western outlaw (www.filmsite.org/biopics.html).

Both sites, however, converge in a very important point to our study. Dirks suggests:

Sometimes, historical biopics stretch the truth and tell a life story with varying degrees of accuracy. Big-screen biopics cross many genre types, since these films might showcase a western outlaw; a criminal; a musical composer; a religious figure or leader of a movement; a war-time military hero; an entertainer; an artist; an inventor, scientist, or doctor; a politician or President; a sports hero or celebrity; or an adventurer (www.filmsite.org/biopics.html).

Brown and Vidal complement the relevance of our study, stating that "in our era of media convergence and the explosion of celebrity culture, the biopic is at the center of a new wave of scholarly interest in transmedia formats (such as the biopic/docudrama hybrids) and the possibilities opened up by a new digital culture obsessed with the self" (www.oxfordbibliographies.com/view/doc ument).

Two subthemes are relevant to our question here: "degrees of accuracy", which also imply subjectivity degrees and hybrid documentaries, as well as the new digital media that stresses the culture of the self, which means that direc- 
tors can feel free to make interactions between professional and private lives of famous people. Steve Jobs (2015), by Danny Boyle, for instance, reveals that the Apple creator had bad temper, especially towards his wife and daughter, in a very one-sided and monological way. Therefore, these non-ethical expositions may obscure, in the future, Jobs' most ingenious Apple creation.

Another problematic biopic was The Social Network (2010), by David Fincher, about the creator of Facebook, Mark Zuckerberg, a Harvard student who was sued by two brothers who claimed that it was their idea. Recipient of more than 150 awards, the biopic was acclaimed and its director was praised for being able to capture the spirit of the age. However, in his first Public Question and Answer, in November 2014, Mark Zuckerberg, founder and chiefexecutive of Facebook, complained about comments implying that he used his social network to find women when, in reality, he was not single but dating his now-wife Priscilla Chan at that time (www.theguardian.com/technology/2014/ nov/08/mark-zuckerberg-social-network-made-stuff-up-hurtful).

Two more biopics have received many complaints. Amy Winehouse's father said his daughter's memories were ruined because of her biopic, Amy (2015), directed by Asif Kapadia. Mitch Winehouse stated that the biopic is "misleading and contains some basic untruths". Emphasizing Amy's abusive use of drugs and alcoholic drinks, the biopic stresses this side instead of concentrating on her qualities as a singer. On the other hand, the biopic received 30 awards. Another biopic that caused controversy was Grace of Monaco (2014). Prince Albert of Monaco and his two sisters, Princess Caroline and Princess Stephanie complained that the biopic is 'pure fiction, innacurate'. They said in a statement to Ben Child from The Guardian, on January 17, 2013:

We have had absolutely no association with this project, which claims to be about the lives of our parents. For us, this film does not constitute a biographical work but portrays only a part of her life, has been pointlessly glamorised and contains important historical inaccuracies as well as scenes of pure fiction (Child, 2013).

Although these examples suggest inaccuracies that cannot be taken as factualities, having received heavy criticism from most film critics, Scorsese biopics can be considered worth of analyses, considering the creation of special formats and tones for each of the protagonists, in a way to reveal their lifestyles.

\section{A Tribute-Biopic}

Martin Scorsese has built his name in fiction, so this fact can justify the choice to analyze his documentaries, which are not so well known. We are 
dealing with documentaries and their variants, such as fake, docudramas, dramadocs, mockumentaries and so on. Biopics or biographical documentaries also have branches that differentiate them, although their convergences remain.

Dennis Bingham, in his book Whose lives are they anyway? states that

like any genre that dates back nearly to the beginning of narrative cinema, the biopic has gone through developmental stages, emerging from each of its historical cycles with certain modes that continue to be available to filmmakers working in the form. These are: the classical, the transition of a producer's genre to auteuristic director's genre (Martin Scorsese, Spike Lee, Oliver Stone, Marry Harron, Julien Schnabel); the Citizen Kane mode; the parody or anti-biopic; the minority appropriation; and, since 2000 , the neoclassical biopic with all or most of these elements (2010: 17).

In his text "The lives and times of the biopic", Bingham complements his ideas commenting that the majority of biopics does not include childhood scenes and isn't a birth-to-death chronicle (Bingham, 2013: 235). Most of them open only when the subjects become famous. This is not the case of George Harrison: living in a material world (2011), in which Scorsese wants to find out about George's thoughts and his way of life, going deeply in his childhood, his affiliation to Hare Krishna, his meditations and even his quarrels and divergences with The Beatles. The title of the biopic clarifies Scorsese's search that follows the same steps as George's and his self-knowledge development.

Asked about the reason for his interest in George Harrison and the Beatles, Scorsese answered that spirituality is for him an interesting subject:

That subject matter has never left me... The more you're in the material world, the more there is a tendency for a search for serenity and a need to not be distracted by physical elements that are around you. His music is very important to me, so I was interested in the journey that he took as an artist. The film is an exploration. We don't know. We're just feeling our way through (Carlick, 2012).

In fact, the 208 minutes biopic intends to examine every possibility to define George's character and his qualities. Although some critics say that Scorsese overpraised Harrison, we believe that the director wanted to leave a memory that could provide a recognition in the future for his life searching for spirituality. Peter Bradshaw, in his review to the Guardian (sep29, 2011), suggests that the biopic is

an enormously affectionate, enthusiastic, and wildly indulgent three-and-ahalf hour docu-tribute to Harrison. With new interviews with key figures including Paul McCartney, Ringo Starr and George Martin, Scorsese's movie sets out to cherish and rediscover that special something in Harrison's music and his gentle, self-deprecating, otherworldly personality. He pays tribute to 
Harrison as the inventor of the benefit gig with his 1971 Bangladesh concert, and also as a film producer and backer of HandMade Films (Bradshow, 2011).

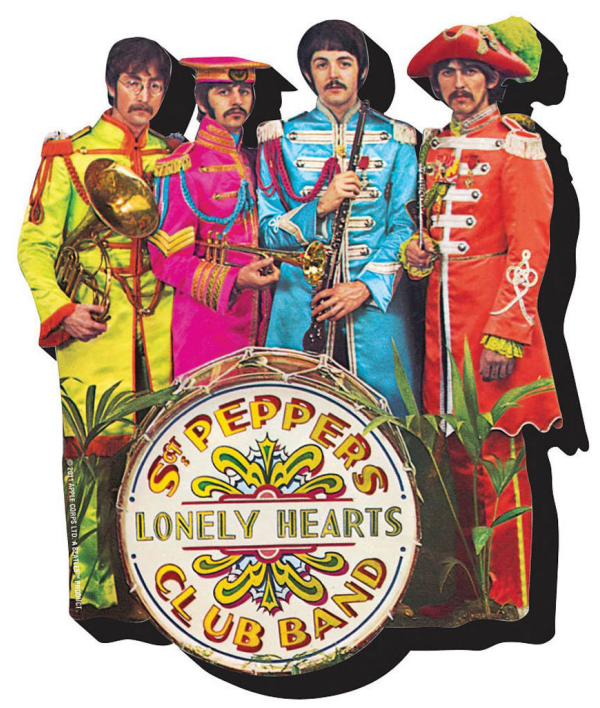

The point that interests us in this study is, however, the way the biopic is structured. We would say that the puzzle-like nonlinear narrative seems to be close to a rhyzome, the Deleuze-Guattari concept that includes plateaus and escape lines. In the first part, Harrison was well adjusted to the band, happy with his role and with Paul McCartney and John Lennon as composers, and the biopic develops a nice and calm plateau, focusing on The Beatles success and creativity. The Club Band St. Peppers "Lonely Hearts" was the climax of the band (image above). After some time, though, Harrison wanted to be a composer too, which created some problems. It was an escape line that disturbed the plateau. Growing up, having a band and conducting their private lives was too much for the Beatles. Paul McCartney was the first to leave. Harrison, trying to find his spiritual live in a material world had to leave too.

The biopic mixes up times and locations, and also images and interviews. One of the most creative strategies of the biopic is that Scorsese does not say anything. There is no voiceover and the interviews and images convey all meanings. The collage, made of invitations, postcards, show programs, songs, drugs, discos, heavy drinks and interviews, Indian sitars and meditation, follows the crazy life of the band, making interactions with high speed, up to the moment of the Jack Stewart car race, in a metaphor of that life that was making them look for peace away from fans and in silence. In the beginning they liked 
having so may fans, but after some time it became impossible to cope with so many commitments and the changes of their own lives.

Spatiality and spirituality are two concepts that are emphasized in the biopic. Harrison moves constantly and the camera seems to accompany him in his new places, thoughts, and searches. The Taj Mahal creates an impact as well as life in India, a country where Gandhi implemented the idea of peace. Harrison is depicted in his efforts to meditate, to look inside himself, to try to connect to his inner life. His second wife, Olivia Harrison, explains, in her interviews, what their life was like.

The tone of the film is subjective. Although fights and quarrels are displayed, the interviews were done with his friends that also tried to insert some pieces in the large puzzle about his double life, sometimes lonely, other times generous, but always changing ideas and trying new places, songs or ideas. Subjectivity plays an important role in the biopic, considering that each interviewer has one point of view about Harrison. Although this collage produces a polyphonic dialog, and avoids monological interpretation, it is far from the idea of what Harrison was. Perhaps his search just ended with his death, but not with an understanding about his personality or desires.

Beatriz Sarlo, in his book Time past and the subjective turn, believes that "even if memory can function as a moral challenge to history and its sources, this cannot support memories' claims to be less problematic than what is constructed by other discourses". (57). She also believes that memory is part of a subjective turn and that accounts of the past are always constructions. Therefore, in the future, Harrison might be remembered as Scorsese's biopic depicted him, perhaps in a better light than he really was, but nobody knows what he really thought inside himself, so subjectivity wins.

Our argument here goes along the insights defined by Jacques Derrida and his concept of deconstruction. If we take literally his assertion that "there is no outside-text", for spectators in the future George Harrison biopic might be taken as his life. Going further, we could say that Derrida's deconstruction questions certainty and determinacy, as it questions "reality and truth" as well. Taking this path, we can say that Scorsese film follows the idea of questioning who his protagonist were, trying all kinds of sources and opinions, making a collage with voices, songs and images, leaving to spectators to come to conclusions. His biopic does not intend to be the ultimate statement about the Beatles guitarist, but may be taken to one version that can be relevant for the future memory when the Beatles will be only history, legend and myth.

Scorsese's strategies can be considered to be followers of Derrida's: exploring and trying to reveal the internal logic of ideas and meanings, attempting 
to go inside Harrison's mind following the same process that Harrison himself was doing in his search for his inner conception of life. Considering this possibility, the biopic can be taken as a meta-biopic, in its search to find out how a biopic could be constructed.

If we consider that subjectivity is inherent to any representation, biopics imply subjective views as fiction films and documentaries. According to Krysten Arneson, paraphrasing Toby Miller and complementing his remarks:

There is an art to documentary that obliges the filmmaker to choose camera angles, to string words together into sentences that are not just informative but that tell a story an art that draws not from objective methods of representing reality, but the fictive world of cinematic production. The documentary transforms its object into a spectacle of sound and image that draws on signs from the fictive and social worlds. Fictional and factual protocols become tropes of production and reception, as filmmakers and viewers draw on intersecting textual norms to make and decipher meaning(Miller, 1998:184). Despite their presentation, documentaries are not an objective but a subjective device, a medium that "marshal[s] systems of representation to encourage point of view about something (Toby Miller, 1998:183). This inherent subjectivity, drawn not only from the construction of the film but also from the interpretation of the filmmaker, makes it impossible for a documentary to ever accurately represent the everyday (Arneson, https://artifactsjournal.missouri.edu/2012/03/r epresentation-through-documentary-a-post-modern-assessment/).

Regarding testimony and memory for the future, we believe that memory, even subjective memory, is what lasts the most. Therefore, Scorsese's George Harrison: living in the material world will certainly be one of the versions that will endure and complete the puzzle that the biopic proposes.

\section{A Selfie-Biopic}

Some biopics are so focused on one person that could be called selfies. This is the case of Public Speaking (2010), Scorsese documentary about Fran Lebowitz. She is the star from the beginning to the end, self-confident, delivering her lines as she was on the stage all the time. At times, she seems to act as a standup comedian, a little irreverent, making people laugh, answering questions in her ironic tone that can be funny. Even when she is in the middle of personalities such as James Baldwin, Toni Morrison and so on, she finds a way to be the smartest one. She confesses that she loves when people ask her opinion, when she is allowed to have a large audience, when she can be the center of attention.

According to Laura Rascaroli, in her chapter about self-portraits in the book The Cinema of Me: the self and subjectivity in first person documentary, "similarly to the literary self-portrait, the audiovisual one has much to 
do with the monologue, in which the spectator is in the position of an overseeing/overhearing third person" (Rascaroli, 60). In fact, this seems to be the case. The documentary shows Lebowitz having dinner at the Waverly Inn, whose wall next to her table displays a caricature of her by Edward Sorel. She is also shown in presentations with large audiences and even in a Jeopardy TV show in which there are three competitors in the Quotable Fran Lebowitz category.

In some moments Lebowitz comes up with serious comments, for instance when she explains her ideas about the difference between opinions and news, complaining that media, journalists and reporters, instead of offering us information are giving spectators their comments about every topic. She believes that media should have less authority about news and should inform more than express opinions.

Her comments about television suggests that, in the beginning, people were afraid nobody would pay attention to it, considering that there were so many other distractions in a house, but finally it was the opposite, the whole world came to television and now television is the world. She also complains that there are too much democracy for literate people and too little for the illiterate ones. One interesting detail is that, being a Jew, she also uses the selfdeprecation formula so familiar to Woody Allen's persona, calling herself as "the most slothful person in America".

Lucy Mangan, in her review to The Guardian (2011) describes the film:

The film is in essence a monologue occasionally intercut with archive footage of 70s New York and heroes such as James Baldwin, as Lebowitz expounds on . . . well, just about everything. Entire cultural movements, vast swathes of social change are effortlessly distilled into beautiful, brutal epigrams "Too many people are writing books, the books are terrible and this is because you have been taught to have self-esteem," she explains to another audience member. The rise of celebrity worship is explained as a Warholian joke "that got into the water supply" and the difference between wit and humour summarised as "warmth. Wit is cold. It is judgment" - and dispensed from "her" booth at the Waverly Inn (Mangan, 2011: www.theguardian.com/tvand-radio/2011/feb/01/public-speaking-fran-lebowitz-scorsese).

Mangan also mentions: "It's shot in the style of his early documentaries, Italian American and American Boy-energetic, sinewy, beautiful-but perhaps 'documentary' is a slightly misleading term" (idem). That is the reason we call it a "selfie-biopic".

Talking about what would be labeled as delicate matters nowadays, when political correctedness is so emphasized, Lebowitz deconstructs the LGBT lobby's causes of homo marriage and gays in the military with an ironic "Are you kidding me? You want the two most confining institutions, marriage and the 
Army? Usually a fight for freedom is a fight for freedom- this is the opposite!" She also feels nostalgic about gay bars where smoking was allowed. She states that she was happy to have Obama so "we can get over" the whole business of having a black President. She also makes comments about former President Bush and his Iraq Study Group. She metaphorically compares it to a thirdgrader facing a math test: "is the best time to study the night before the test or three years afterward?" Whether she is sarcastic or ironic, self-confident or over-confident, she knows how to entertain with wit and grace.

Having Lebowitz running the show was a very intelligent strategy by Scorsese, and also the most intricate problem to classify the documentary. Would it be considered a documentary when we do not have any testimony of anybody else except of she-herself talking about herself? Could her comments be taken seriously when she sometimes seems to be a standup comedian? Did she create a "persona" like Woody Allen? Or is she really like this? Isn't it too subjective to be considered her life?

These questions may be answered if we attempt to verify to which point Persona and Jewish humor are relevant to Lebowitz's witty public speaking. According to Irving Howe, Jewish humor is "an irony which measures the distance between pretension and actuality" (19). Characteristics of Jewish humor are self-mockery or self-deprecation, skeptical outlook and exaggeration. Stora-Sandor explains that Jewish people have inherited, from earlier generations, a mental habit which leads them to analyze everything based on every possible angle, finding the most subtle answer to complex questions" (48). Lebowitz displays most of Jewish Humor characteristics, when she says she couldn't tell the hour until she was nine, she was never doing homework, as a child she was fearful of normal activities, she was bad at Math and she still counts on her fingers, she is very lazy, she hates all jobs, never had a job she liked, she hates tourists in New York, she is a horrible girlfriend. Besides being characteristics of Jewish Humor, there is also a kind of performance in her acts that could be classified as a persona, especially in her public appearances.

Roy Patterson, in his article "Free-range performance artist", at the Slate, defines: "Fran Lebowitz, ace epigrammatist, is further a first-rate conversationalist, a hall-of-fame bibliomaniac, a chronic self-caricaturist, a gal-about-town, the soul of the city, a snappish social critic, a snappy dresser, a popular emcee, a mandarin, a mascot, and the least-prolific great humorist of the American experiment" (Nov 22. 2010). Patterson continues: At 60, Fran is 29 years late turning in a novel to Knopf, and in Public Speaking she claims for herself a perverse superlative: 
I'm the most outstanding waster of time of my generation. The book, Exterior Signs of Wealth, is not coming along nicely. I moved a couple of months ago and so I saw it in the bottom of a box. The half of it that exists holds up. I found that I'm sure I still agree with myself.... On stage before an audience with her pal Toni Morrison, she defines the difference between humor and wit and sounds like a culture minister without portfolio (Patterson, www.slate.com/articles/arts/culturebox/2010/11/freerange_performance_arti st.html).

Besides being funny, her persona mixes comments that are self-deprecating with higly hyperbolic one such as "That's the problem with being ahead of your time," Lebowitz says in Public Speaking. "By the time everyone catches up with you, you're bored."

The concept of "persona" has been defined in many instances, such as the Wikipedia, that includes its origin and development. For our case, however, the definition could be "a social role or a character played by an actor... although the origin of the term is not completely clear, persona could possibly be related to the Latin verb per-sonare, literally: sounding through, with an obvious link to the theatrical mask". The persona, for Swiss psychiatrist Carl Jung, is the social face the individual presented to the world- "a kind of mask designed on the one hand to make a definite impression upon others, and on the other to conceal the true nature of the individual."

Laurence Scott, in the abstract of his article The Ethical Camp and mute elegiac of Fran Lebowitz states that

Lebowitz combines the theatricality of traditional camp with ethical seriousness in her public, performed identity as self-appointed judge of contemporary American life. At the same time, in the ironic gap between the verbosity of her identity as public speaker and her own paralysed literary output, Lebowitz enacts a tacit elegy to a 'lost public' of New York artists and their equally decimated audience (Scott, 2012).

The most appropriate usage here would be a "theatrical mask" which functions as a comic strategy to entertain at the same time as it implies an irony in its remarks and comments. Saying those remarks in a serious tone is another strategy to produce laughter. Edward Sorel, the cartoonist, could encapsulate Lebowitz style and mood in his work depicting her caricature in the Waverly Inn Mural below. 

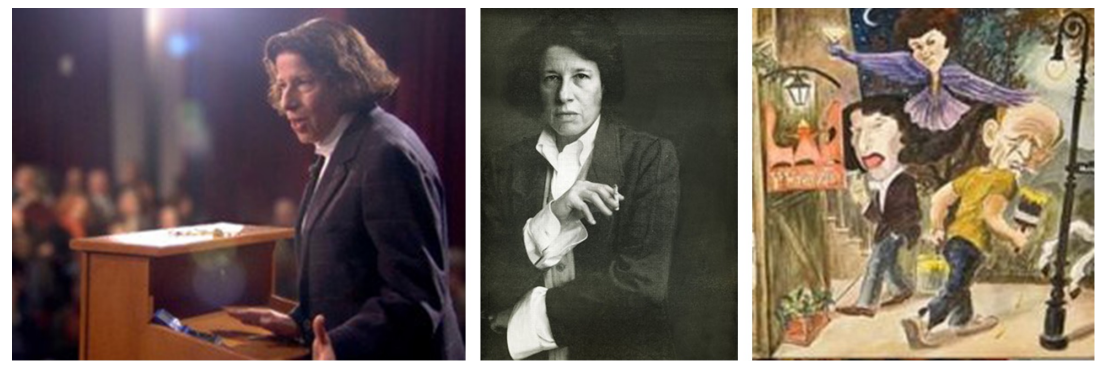

These three images of Fran Lebowitz summarize her performance through the documentary, which we denominated as a "selfie-biopic". In the first image, she is talking to a large audience; the second image reveals her, smoking, in her "man suit", as she calls her most used kind of clothes; the third image show her caricature next to her habitual table as she explains in one of her meetings at the Waverly Inn restaurant.

\section{An Accomplice-Biopic}

According to Todd McCarthy, in his review for the IndieWire, A Letter to Elia is

an intensely personal and deep exploration of the essence of one major filmmaker by another. Keenly analytical in its appreciation of how Elia Kazan achieved such dramatic power in his best work, the hour-long piece movingly achieves special status in the way Scorsese uses the occasion to offer a penetrating slice of emotional autobiography, one man revealing much about himself through his affinity for another man's cinema (www.indiewire.com/2010/ 09/review-a-letter-to-elia-228011).

Following McCarthy's insightful comments, we would say that the biopic reveals a complicity of the two directors not only in the impression Elia's films had on Scorsese but also in the way that the biopic is developed in its interconnections between clips and voice over and remarks, producing a net of dialogical effects as spectators could almost see or at least imagine Scorsese's feelings in watching the same films over and over. There are three concepts that can be adapted to explain this case: the term "dialogism" in the sense that Mikhail Bakhtin describes his concept, if we focus our analysis in the two directors and their connection; the term "polyphony" if we include interviews and comments that can offer many voices and can allow many points of view; and "intertextuality", in the sense Julia Kristeva coined it, as the process of one text interaction with the other in the documentary narrative. 
When Bakhtin created the term "dialogism", he meant to describe texts in which there is not only one single-minded voice and where at least two voices can be heard. This is what happens in the biopic when Kazan's film images are intertwined with Scorsese's comments. When more voices are added, we can adapt Bakhtin's concept of "polyphony". Coming from the area of Music, the term defines a multiplicity of voices that also interact in a web that can also allude to the term "intertextuality", if taken in consideration the interchange between the two texts, one by Scorsese and the other by Kazan. This intertextuality can lead to a relationship of devotion and exchange. McCarthy recalls these words : "I was living through the film," explaining that Scorsese reflects as he vividly conveys the common experience of finding an emotional outlet in the movies that it is impossible to have with family during adolescence (www.indiewire.com/2010/09/review-a-letter-to-elia-228011).

Julia Kristeva, who coined the term "intertextuality" after Mikhail Bakhtin's concepts of dialogism and polyphony, states, in her well known definition, that "any text is constructed of a mosaic of quotations, any text is the absorption and transformation of another" (Kristeva, 1980:66). In the case of the documentary A Letter to Elia, the process is double: Scorsese interacts with Kazan's films and at the same time he remembers his youth. Subjectivity and memory go together, and spectators have the clips of Kazan's films reviewed and filled with personal comments about Scorsese's past and present. Adapting Kristeva's concept of intertextuality, we can argue that the "mosaic of quotations" may refer to the filmmaker's comments, which are absorbed by the clips and transformed into a collection of thoughts and ideas. Regarding the coined term we are proposing, "accomplice-biopic", we can argue that it refers to Scorsese's continuous exchange with Kazan, but especially about the sad incident when Kazan denounced his companions as communists. Scorsese, who actually presented Kazan with his Oscar in 1989, tries hard to justify it, as an accomplice would do. 


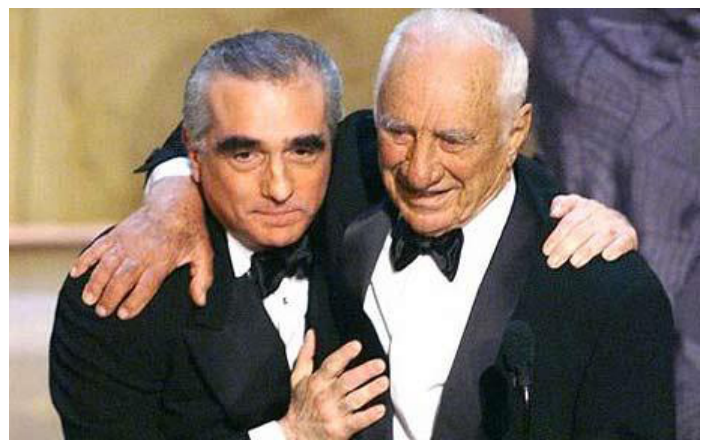

According to McCarthy,

You can't discuss Kazan for three minutes without the blacklist coming up, but this film uses it as way to help explain the indisputable change and improvement his HUAC testimony triggered in Kazan's work. "This was the moment a director became a filmmaker," Scorsese says here, not as an excuse or justification, but as a psychological observation about emotional cause and artistic effect (www.indiewire.com/2010/09/review-a-letter-to-elia-228011/).

In 1952, Kazan had appeared before the House Committee on un-American Activities and named eight of his old friends from the Group Theater who in 1930s, along with him, had been members of the American Communist Party. When Kazan was 89 years old and received his honorary Oscar, at the $71^{\text {st }}$ Annual Academy Awards Ceremony, some applauded him and some didn't, which proved that his action was not forgotten. Although Kazan never apologized for his testimony, some were on his side, including Scorsese. Kazan's masterpieces were considered more important than his testimony. Some of his plays and films are cited in Scorsese's biopic A Letter to Elia, focusing especially in A street car named desire, the play and the film, On the Waterfront, East of Eden and America America.

McCarthy complements:

Scorsese's phrase "I was living through the film," reflects as he vividly conveys the common experience of finding an emotional outlet in the movies that it is impossible to have with family during adolescence....By mixing the authenticity of his initial emotional response to Kazan's films with his vast cinematic erudition, and by deciding to largely jettison the usual documentary baggage of archival footage, interviews with associates and Hollywood history factoids, Scorsese has been able to concentrate nearly all their attention on that which is of the greatest value in Kazan's work and to throw an intense spotlight the man's complexity and distinction as an artist (www.indiewire.com/2010/09/review-a-letter-to-elia-228011/). 
Besides being a source of Scorsese's inspiration, Kazan represented in some of films the same environment in Little Italy, as both of them shared, having come from foreign country families. On the Waterfront reveals features of protagonists that were familiar to Scorsese, making him understand those lives and later revives them in his own films.

East of Eden is connected to his own childhood, his family and his relationship with his brother. Watching the brotherly conflict between Cal and Aaron in Kazan's film touched him deeply when he was 12. Scorsese's identification with themes and the way Kazan represented them were one of the reasons for his accomplice-biopic.

A Letter to Elia follows what Bill Nichols calls of "participatory or interactive mode", which presents the relationship between the filmmaker and the filmed subject. In fact, Scorsese investigates clips of films making an intimate connection with them.

The participatory documentary reveals the director's point of view in a clear way, involving him in the discourse and narrative. The filmmaker makes contact with his protagonist in a direct way and explains to the audience in person, making his appearance as part of the biopic, as a participant of the narration. Besides, the chosen interviews seem to collaborate providing multiple voices, reconstructing events, going to the past, remembering old impressions, adding new ones (Nichols, 1991: 78-93; 2001: 115-125).

\section{Conclusion}

Nichols' ideas about documentaries can describe them in an objective way:

Each film establishes internal norms or structures of its own but these frequently share common traits with the textual system or organizing pattern of other documentaries. Documentaries take shape around an informing logic. The economy of the logic requires a representation, case or argument about the historical world. The economy is basically instrumental or pragmatic: it operates in terms of problem-solving. A paradigmatic structure for documentary would involve the establishment of an issue or problem, the presentation of the background to the problem, followed by an examination of its current extent or complexity, often including more than one perspective or point of view. This would lead to a concluding section where a solution or path toward a solution is introduced (Nichols, 1991: 48).

However, the three documentaries analyzed in this text differ in one important point not mentioned above: the subjectivity inherent to the them, which makes them more authentic in terms of creativity and careful approach to each one of them, developing the protagonists in a personal way, taking into account their way of life, and choosing strategies that could contemplate their views. In 
counterpoint with the many biopics that do not offer what protagonists deserve, Scorsese's attempts to produce relevant biopics go beyond common usage or documentary rules.

In his work Blurred Boundaries (1994), Nichols summarizes the current state of the documentary as follows:

Traditionally, the word documentary has suggested fullness and completion, knowledge and fact, explanations of the social world and its motivating mechanisms. More recently, though, documentary has come to suggest incompleteness and uncertainty, recollection and impression, images of personal worlds and their subjective construction (Nichols, 1994:1).

This citation is appropriate to describe the corpus of our text: documentaries that work with "recollections and impressions, images of personal worlds and their subjective construction". If subjectivity is recognized now as one of the elements of documentaries, we can say that Scorsese's biopics will be a source of knowledge and memory for the three biopics.

In our analyses, we also tried to perceive strategies adopted by Scorsese as well as significant elements that were part of the three protagonists. Scorsese allowed Lebowitz to act freely in his/her Public Speaking; he went deeply in Harrison's mind to be able to verify what moved him towards preparing his body to death; he accompanied Kazan through his plays, films and awards. These are the reasons we coined the three kinds: a selfie-biopic, a tributebiopic and an accomplice-biopic respectively.

In our choice of theoretical references, we also took into consideration Beatriz Sarlo's views on memory, Julia Kristeva's concept of intertextuality, Fernão Ramos' ideas about documentaries, Bill Nichols' classification and Deane Williams' analysis of Grierson. Besides, the book The Biopic in Contemporary Film Culture, edited by Tom Brown and Belén Vidal, brings many comments to the analyses of biopics, stating that "like other forms of the heritage film, the modern biopic has become a site of competing memories... Memory and History have become central questions in the study of the biopics as an international genre" (p. 22-23).

Actually, the renewed interest in producing biopics has been growing lately. From Abel Gance's bio-epic Napoléon (1927), the change from chronology to personality became evident, as the emphasis on gestures and styles, subverting linear time and chronology. This is the case of Scorsese's three biopics. Each one focuses the protagonist way of life trying to encapsulate the inner feelings, the soul of the chosen protagonists: Lebowitz satisfies her desire of conduct public speeches; Kazan has the filmmaker at his side all the time to honor him; and Harrison's intimate doubts and quests are taken seriously. 


\section{Bibliographic references}

Arneson, K. (2012). Representation through documentary: a post-modern assessment. Artifacts Journal. Missouri Univ. Avaliable in: https://artifacts journal.missouri.edu/2012/03/representation-through-documentary-a-po st-modern-assessment/

Bakhtin, M. (1984). Problems of Dostoevsky's Poetics. Minneapolis: Univ of Minnesota Press.

Batty, D. \& Johnston, C. (2014). Question and Answer with Mark Zuckerberg social network. Avaliable in: www.theguardian.com/technology/2014/no v/08/mark-zuckerberg-social-network-made-stuff-up-hurtful

Bingham, D. (2010). Whose lives are they anyway?. New Jersey: Rutgers UP.

Bradshaw, P. (2011). Review George Harrison. Avaliable in: http://theguardia n.com/film/2011/sep/29/george-harrison-material-world

Brown, T. \& Vidal, B. (s/d). Oxford Bibliographies. Avaliable in: www.oxford bibliographies.com/view/document

Carlick, S. (2012). Martin Scorsese to unveil George Harrison Documentary. Exclaim. New Jersey: Rutgers UP.

Carroll, N. (1996). From real to reel: entangled in non-fiction film. In Theorizing the Movie Image. Cambridge: Cambridge UP.

Child, B. (2013). Nicole Kidman's Grace Kelly biopic “inaccurate” say Monaco Royals. Avaliable in: http://www.theguardian.com/film/2013/jan/17 /nicole-kidman-grace-kelly-biopic-innacurate

Deleuze, G. \& Guattari, F. (1995). Mil Platôs: capitalismo e esquizofrenia. SP: Ed. 34.

Dirks, T. (s/d). Biopics Films. In Filmsite. Avaliable in: www.filmsite.org/bio pics.html

Kristeva, J. (1980). Desire in Language: a semiotic approach to Literature and Art. Ed. Leon Roudiez, T. Gora et al. NY: Columbia UP.

Mangan, L. (2011). Cable Girl: Public Speaking. Avaliable in: www.theguar dian.com/tv-and-radio/2011/feb/01/public-speaking-fran-lebowitz-scors ese

Matuszewski, B. (1898). Une nouvelle source de l'histoire du cinéma (Création d'un dépôt de cinématographie historique). Paris.

McCarthy, T. (2010). Review A letter to Elia. Avaliable in: www.indiewire.co $\mathrm{m} / 2010 / 09 /$ review-a-letter-to-elia-22801 
Miller, T. (1998). Technologies of Truth: Cultural Citizenship and the Popular Media. Ed. by Michael Renov, Faye Ginsburg, and Jane Gaines. Minneapolis: University of Minnesota Press.

Nichols, B. (2001). Introduction to Documentary. Bloomington \& Indianopolis: Indiana UP.

Nichols, B. (1991). Representing Reality: Issues and Concepts in Documentary. Indianapolis: Indiana UP.

Nichols, B. (2001) How do documentaries differ from other types of film?. In Introduction to Documentary. Bloomington \& Indianopolis: Indiana UP.

Patterson, T. (2010). The new Fran Lebowitz documentary. Free-range performance artist. Avaliable in: www.slate.com/articles/arts/culturebox/2010/ 11/freerange_performance_artist.html

Penafria, M. (1999). O filme documentário. História, identidade e tecnologia. Lisboa: Edições Cosmos.

Rabinowitz, P. (1994). They must be represented. London: Ed. Verso.

Rascaroli, L. (2012). The self-portrait film: Michelangelo's last gaze. In The Cinema of me: the self and subjectivity in first person documentary. Ed. Alisa Lebow. NY: Columbia UP.

Ramos, F. P. (2008). Mas afinal... o que é mesmo documentário?. SP: SENAC.

Sarlo, B. (2007). Tempo passado: cultura da memória e guinada subjetiva. SP: Companhia das Letras; Belo Horizonte: UFMG.

Scott, L. (2012) Notes on Fran: the ethical camp and mute elegiac of Fran Lebowitz. In Research Gate GMBh. Berlin. Avaliable in: www.researchg ate.net/publication/285701459_Notes_on_Fran_The_Ethical_Camp_and _Mute_Elegiac_of_Fran_Lebowitz

Stora-Sandor, J. (1984). L'humour juif dans la literature: de Job a Woody Allen. Paris: Presses Universitaires de France.

\section{Filmography}

A letter to Elia (2010), Martin Scorsese.

Amy (2015), de Asif Kapadia.

George Harrison: living in the material world (2011), de Martin Scorsese.

Grace of Monaco (2014), de Olivier Dahan.

Public Speaking (2010), de Martin Scorsese.

Steve Jobs (2015), de Danny Boyle.

The Social Network (2010), de David Fincher. 